\title{
Trends in James Baldwin Criticism, 2015-16
}

\author{
Jenny M. James Pacific Lutheran University
}

\begin{abstract}
This review article charts the general direction of scholarship in James Baldwin studies between the years 2015 and 2016, reflecting on important scholarly events and publications of the period and identifying notable trends in criticism. While these years witnessed a continuing interest in the relationship of Baldwin's work to other authors and art forms as well as his transnational literary imagination, noted in previous scholarly reviews, three newly emergent trends are notable: an increased attention to Baldwin in journals primarily devoted to the study of literatures in English, a new wave of multidisciplinary studies of Baldwin, and a burgeoning archival turn in Baldwin criticism.
\end{abstract}

Keywords: James Baldwin, African-American literature, literary criticism, multidisciplinary, archive

This scholarly review builds on the important essays published in past volumes of the James Baldwin Review (JBR) by Conseula Francis, Lynn Orilla Scott, D. Quentin Miller, and Ernest L. Gibson, who have provided substantive and illuminating reflections on important trends in James Baldwin criticism since 1963. In the following pages, I continue to chart the general direction of scholarship in the field of James Baldwin studies, looking in particular at scholarly events and publications that emerged between 2015 and 2016. A transformative moment for Baldwin scholarship, we saw during these years a remarkable rise in public interest in James Baldwin's work and life, on a national and a global stage. This increase in popularity is in many ways a predictable extension of the steadily climbing arc of Baldwin criticism over the past twenty years. The revitalization of public discourse about Baldwin was fostered by scholars and artists who organized cultural festivals, art exhibits, academic conferences, and media platforms to celebrate his life and words. Yet beyond any academic or artistic incubator, contemporary society's passionate quest to learn

James Baldwin Review, Volume 5, 2019, (c) The Authors. Published by Manchester University Press and The University of Manchester Library 
more from Baldwin's uniquely prophetic writings during these years was intensified by the electric tensions that took hold of the U.S. in the wake of the killings of Trayvon Martin, Eric Garner, Michael Brown, Sandra Bland, and many others.

Witnessing the development of the social media hashtag \#BlackLivesMatter and associated protest movements for racial justice, Americans turned to Baldwin as a means of elucidating the sociocultural history of white supremacy in America. Searching for the reasons why its toxic presence still endures, American readers sought a way out of the nation's proverbial house on fire. By the summer of 2015 when the election season for the 45th president was well under way, the diametrically opposed political platforms of Hillary Clinton and Donald Trump confirmed that the fantasy of white dominance was crumbling in the face of an increasingly racially diverse national reality, but not without a battle of serious moral consequence. Foreseeing the election's obfuscating rhetoric that sought to erase the lived reality of racist violence, Frederick C. Harris writes in his 2014 article "James Baldwin, 1963, and the House that Race Built:" "In this age of falsity and insane cruelty, now more than ever do we need Baldwin's rawness, his steadfastness, his not forgetting to see the world through the eyes of the other." By 2014, it was clear that Baldwin's voice needed to be amplified.

That same year marked the 90th anniversary of James Baldwin's birth, a celebrated milestone that catalyzed a wealth of tributes to, and creative re-visions of, Baldwin's work and legacy that took hold of the U.S. Of these events, New York's "Year of Baldwin," punctuated in particular by the week-long 2014 New York Live Arts Festival dedicated to "James Baldwin, This Time!," takes center stage. Co-organized by Bill T. Jones and Lawrence Weschler, the festival brought together important Baldwin scholars, such as David Leeming, Rich Blint, and Matt Brim, with such authors as the inestimable Jamaica Kincaid, Sharifa Rhodes-Pitts, Yusef Komunyakaa, and Colm Tóibín, visual artists Carrie Mae Weems and Sanford Biggers, choreographers Charles O. Anderson and Dianne McIntyre, and the singersongwriter and playwright, Stew. While focused on the art and literary community in New York City, this event illustrates the enlivening impact that Baldwin has had on contemporary life more broadly-a cultural impact that touches upon deeper, more artistically varied, and intellectually complex sites of artistic practice and reception than any tweet or soundbite of Baldwin's highly quotable archive might suggest. We can see Baldwin's legacy at play in Ta Nehisi-Coates's 2015 memoir Between the World and Me, as Ernest L. Gibson argued in last year's JBR review of scholarly trends, as well as in Barry Jenkins's luminous, Oscar-winning 2016 film Moonlight.

Although Baldwin's 90th birthday occurred a year prior to the timeframe of this scholarly overview, it set the tone of remembering and reclamation that continued in the years that follow. Reporting on her experiences attending "The Year of Baldwin" events in the first volume of $J B R$, Michelle Elam notes that in readings, scholarly panels, and community forums, participants worried over the potentially waning public reception of Baldwin; she writes, however, that "the fact that Baldwin's political and artistic legacies remain unsettled and unsettling is precisely what gives the 
city-wide, year-long multidisciplinary festival celebrating Baldwin ... much of its freshness. The opening week had more the flavor of a revivalist retreat than an academic conference." In the context of this urgent, transitional moment, the academic and popular publication record during 2015-16 seems to suggest that Baldwin's immeasurable contribution to American culture has become increasingly recognizable in the public sphere, even while his many lives and ideas are contested.

The creative, celebratory energy of the "Year of Baldwin" traveled across the Atlantic in May of 2016 when perhaps the most well-attended International James Baldwin Conference took place in Paris, hosted by Alice Mikal Craven and William E. Dow at the American University of Paris. Centering on the theme of “'A Language to Dwell In:' James Baldwin, Paris, and International Visions," this fifth biannual conference drew a wide diversity of artistic and scholarly perspectives to advance the academic field of Baldwin criticism and foster creative collaborations between artists, activists, and academics. A number of panels at the conference featured discussions with contemporary artists whose work responds to Baldwin's literary legacy, such as Kleaver Cruz, Imani Uzuri, Jake Lamar, and the London-based collective sorryyoufeeluncomfortable, among others. In turn, another good portion of panels focused on Baldwin and the arts, including papers studying music, film, and performance, as well as quite a few on Baldwin's engagement with visual art. Notable to this conference was its intergenerational, interracial, and sexually diverse tenor; there was a strong showing from a younger community of black, queer, and trans scholars and artists who demonstrated the great potential for future transformations in the field. The highpoint of the conference was a memorable lecture given by Robert Reid-Pharr held at the U.S. Embassy in the ballroom of the Hôtel de Talleyrand, an eighteenth-century gilded room that was packed to the brim for the event. Symbolically flanked by the French and American flags, Reid-Pharr spoke of the opportunity, and price, of carrying Baldwin's weighty legacy, and warned his audience-particularly his younger colleagues-of the need to take care of not just Baldwin's legacy, but one's own life too. His radical, eloquent words illuminated the personal and political motivations of scholars' ardent interest in Baldwin's work, a field of study which for many holds much more meaning than mere intellectual pursuit.

The state of the field of Baldwin studies in 2015-16 appears to be as impassioned, politicized, and abundant with dynamic intellectual debates as its conferences and events. Turning to the publication record of the period, the general direction of scholarship demonstrates an increasing attention to Baldwin given in traditional journals primarily devoted to the study of literatures in English and exhibits a new wave of multidisciplinary and archival approaches to Baldwin criticism, while continuing past trends. Echoing observations made in Miller's and Gibson's overviews of scholarship produced within the first five years of our current decade, critics in 2015-16 continue to pursue scholarly questions relating to Baldwin's literature and other art forms, to Baldwin's transnational literary imagination, and to his connection to other authors and literary works; in turn, they remain, as Gibson describes, drawn "to the familiar" in Baldwin studies. ${ }^{3}$ 
One such example of turning back to the "familiar" is a persistent interest in Go Tell It on the Mountain (1953). Markedly, the two scholarly articles published on Go Tell It that appeared in 2015-16 demonstrate a new attention being shown to more canonized works of Baldwin by long-standing journals of literary criticism. Appearing in 2015, Andrew Connolly's article on the themes of shame and violence in Baldwin's first novel was the first essay devoted solely to James Baldwin to be published in The CEA Critic, the 82-year-old journal of the College English Association. Here Connolly provides an in-depth account of the Black Holiness Church and its strict moralistic system of gender and sexual norms to reveal the deleterious impact of religious guilt and shame on the novel's patriarch, Gabriel Grimes. Connolly contends that Gabriel's violence is a product of this shame, which Baldwin's ambivalent treatment of John Grimes's conversion serves to question. Mason Stokes's 2016 essay “'A Brutal, Indecent Spectacle’: Heterosexuality, Futurity, and Go Tell It On the Mountain" appeared in Modern Fiction Studies, one of only three articles on Baldwin published in this highly selective journal since 1989; more than 35 articles were published in MFS on Toni Morrison during this period while only three appeared on Richard Wright. Here Stokes explores Baldwin's critique of heterosexuality and its "spectacular failure ... to ensure the future, a failure that ultimately severs heterosexuality from its procreative logics and justifications." ${ }^{4}$ Applying a queer analytic lens to Baldwin's novel, Stokes provides a deft rebuttal to Lee Edelman's classic text on queer anti-sociality, No Future: Queer Theory and the Death Drive (2004), claiming that "what Baldwin makes clear is that queer resistance to reproductive futurism only makes sense if there's a future to surrender." ${ }^{5}$

An increase in the publication of articles on Baldwin in more traditional journals of literary criticism during 2015-16 might suggest a parallel increase in the canonicity of Baldwin's oeuvre, particularly of his early works. I make this observation not to reify an English literary canon, but rather to consider the broader reach and appeal of Baldwin's literary contributions in the academy. This trend does not point to any radical undoing of the white Eurocentric construction of literary canons more broadly, but it does ask us to contemplate the question of why we categorize Baldwin within particular periods, fields, or thematic specializations, and what value an expansion of these homes might bring to our understanding of Baldwin's works more generally.

Mirroring the keen focus that the 2016 International James Baldwin Conference brought to Paris as an established object of fascination in Baldwin scholarship, a number of articles published between 2015 and 2016 turned to re-evaluate the historical and cultural meanings of this important setting for Baldwin's life and work. This thematic and geographical attention to Paris, indicating a continuing trend of interest in Baldwin's transnational ties, also demonstrates a further representation of Baldwin's Parisian writings in journals of literary criticism focused on the U.S. and the greater Anglophone world. In her article "The Paris Paradox: Colorblindness and Colonialism in African American Expatriate Fiction," which appeared in American Literature in 2015, Laila Amine offers a thoughtful 
comparative reading of Baldwin's often overlooked short story “This Morning, This Evening, So Soon” (1960), exploring how Baldwin, Richard Wright, and William Gardner Smith "included North African characters and decolonization issues in their fiction . . . to reconcile the coexistence of a colorblind and a colonial Paris."' Here Amine complicates the idealized portrayal of interracial romance between the African-American narrator and his Swedish wife, Harriet, by highlighting Baldwin's complex depiction of the story's secondary Tunisian protagonist, Boona. Boona's fragile friendship with the narrator illuminates the ways African-American expatriates held ambivalent feelings of affiliation towards the Parisian North African community, whose characterization in the story highlights the violence of colonial-era racism in the supposedly openminded city of lights.

Two additional articles offer new perspectives on Baldwin's best-known Parisian text, Giovanni's Room (1956). Christopher Stuart's 2015 "Finding the Jimmy in James: How James Baldwin Discovered Giovanni's Room in Lambert Strether's Paris" strengthens the long-standing linkages between James Baldwin and his transatlantic predecessor Henry James. Here Stuart reads Baldwin's portrait of David's quest for a paradoxically passionate, yet innocent life abroad in the context of Baldwin's critical engagement with Henry James's novel The Ambassadors, and in particular Lambert Strether's futile efforts to avoid being "down in the dust" with common humanity. ${ }^{7}$ Suzanne Roszak's 2015 "Sex, Diaspora, and the New 'Italian Novel': James Baldwin's Giovanni's Room and Bernard Malamud's Pictures of Feldman" compares Baldwin's and Malamud's revisions of the literary conventions associated with the "Italian novel," making a case for the authors interrupting the binary oppositions of sex and migration found in the works of E. M. Forster and Patricia Highsmith. While Roszak sees Baldwin's characterization of Giovanni in Paris as stereotypical and essentialist, she claims that the fact that David and Giovanni's relationship is set in Paris triangulates the touristic dichotomies found in more traditional texts, thereby opening up a more dynamic and historically grounded account of Italian diasporic culture.

Finally, Spencer Morrison's 2016 publication of "James Baldwin on Vacation in Another Country" in English Literary History, one of four essays on Baldwin published in the journal since 1934, offers an important re-reading of Another Country in the context of Cold War tourism and postwar policies of global economic revitalization and foreign aid. Tying the novel's representation of tourism and exile to the development of "Marshall Plan tourism," which Baldwin was implicitly participating in while in France, Morrison illuminates the impact that the postwar ideology of foreign aid had on Baldwin's conception of identification across social differences. He goes on to astutely argue that the

multiform traversals of literal and figurative borders on display in Another Country demand that critics trace the novel's (and Baldwin's) deceptively layered performances of international mobility at a time when such mobility was being reshaped by political and economic initiatives of reconstruction both within and beyond the 
U.S.-initiatives to reconstruct not only the shattered cities of post-WWII Europe but also the inner cities of U.S. metropolises. ${ }^{8}$

This engaging historical lens allows Morrison to reinterpret important yet overlooked characters in the novel, such as Steve Ellis-the novel's quintessential tourist-and Yves, a character whose plot of development both mirrors, and resists, the fantasy of maturation underlying the U.S. development of the shattered European landscape.

In tracking the advancement of scholarly publication in Baldwin criticism across a variety of academic journals dedicated to literary criticism, it is clear that research on Baldwin in traditional fields of literary studies is growing at a steady pace. Yet the gifts Baldwin offers us cannot be delimited, nor contained within a single academic discipline or field of reception. During his lifetime, Baldwin was a catalyst for the diversification of philosophical and political debate, and his fiction, dramatic works, essays, interviews, and public addresses serve as testament to the democratizing spirit of his gifts as an artist and public intellectual. The wide-ranging generic, cultural, and political scope of Baldwin's work thus demands a multidimensional critical method that bridges various disciplines and intellectual traditions. To engage with Baldwin as a critic today requires one to navigate a greater ethical and political project of engaging multiplicity and tension across differences within and outside the academy. For his work and life call us to strive toward cultivating a publicly accessible body of criticism-one that is attentive to the racial, gendered, and sexual politics that shape cultural and scholarly production - and stay unwavering in our commitment to cultivating a richly diverse, intellectually innovative and historically grounded storehouse of ideas.

Since the founding of interdisciplinary programs in the early 1970s, Baldwin has long been an important subject of study in such fields as African-American studies, jazz studies, cultural studies, and religion. Yet the years 2015-16 saw the reach of Baldwin's writings and ideas expanding into new corners of the U.S. academy. As the public reception of Baldwin's works grew, so too did the study of Baldwin circulate within a diasporic constellation of new scholarly and artistic homes. One of the contributing forces in this expansion was the 2015 publication of the inaugural volume of James Baldwin Review. In light of the relatively sparse attention that journals in the discipline-other than those focused on African-American literature-have shown to Baldwin over the years, the true significance of this journal's multidisciplinary commitment to Baldwin criticism is more certain than ever. The decision of editors Dwight A. McBride, Douglas Field, and Justin A. Joyce to publish $J B R$ as an open-access and multidisciplinary journal with Manchester University Press furthers the goal of accessibility; and the journal's mission to support creative and critical work across academic and national borders is illustrative of the field's dedication to Baldwin's legacy of democratic egalitarianism. Thus, the first two volumes of $J B R$ included a range of scholarly perspectives and subjects of study, including Bill Schwartz's comparative reading of Baldwin and Chinua Achebe, Emma Cleary's analysis of Baldwin's literary cartography, Joseph 
Vogel's essay on Baldwin's response to the 1980s rise of the religious right, and McKinley E. Melton's exploration of black queer identity within the testimonial tradition of the Black Church.

The multidisciplinary power of Baldwin scholarship took on new life in interdisciplinary journals in 2015 and 2016, as well as in more traditionally defined academic disciplines-a second trend in criticism identified during this period. A number of scholars working beyond the confines of traditional literary criticism focused their attention on The Fire Next Time (TFNT), a text often read as the historical axis of Baldwin's shifting political consciousness. Arguably the most widely read work of Baldwin's oeuvre, TFNT takes on new political and social significance when read within the disciplinary contexts of theology, philosophy, and political science. Interpreting the prophetic strains of TFNT alongside the theological framework of "call and response," religious scholar Terrance Dean's essay "Fire This Time: James Baldwin, Futurity and a Call and Response" in Black Theology claims that Baldwin's 1963 publication is suggestive of the liberatory power of Afrofuturism, which the author sees as fundamental to the Black theological tradition of preaching and prophecy. Dean reads Baldwin's sermonic incorporation of the jeremiad and the call-and-response nature of the essay's epistolary frame as serving to envision a redemptive future for black and white Americans, a prophetic valence embodied in the book's memorable final lines that continue to inspire critical attention. Similarly focusing on Baldwin's portrait of Christian love in TFNT, Grant Farred's essay "Love is Asymmetrical: James Baldwin's The Fire Next Time" re-reads Baldwin's invocation of the vulnerable and risky process of Christian love for the Other within the context of Jacques Derrida's theorization of "asymmetry." Blending careful interpretation of scriptural allusion in Baldwin's writings with a consideration of Derrida's discussion of asymmetry within the context of Abrahamic notions of salvation, Farred riffs on Derrida's The Gift of Death (2008) to argue that "Baldwin must make [a] love that has no resemblance to the 'Scribes and Pharisees' who delimit Christianity. Most importantly, Baldwin must 'exceed' his community because the force of asymmetrical love is that it demands, before anything, openness to the Other." In doing so, Farred provides a useful critical example of the important, yet sometimes overlooked, role that critical theory can play in interpreting Baldwin's philosophically complex writings.

Placing The Fire Next Time in conversation with other important nonfiction texts Baldwin published in the 1960s on the subject of racial identity and interracial solidarity, Lisa A. Beard articulates Baldwin's crucial contribution to the field of political science in her 2016 article "Flesh of their Flesh, Bone of their Bone': James Baldwin's Racial Politics of Boundness." Here, Beard coins the term "boundness" to describe the embodied and moral kinship Baldwin imagines as inseparably bounding black and white Americans, a political theory which frames both interracial violence and movements for racial justice as premised upon an intimate, intra-familial relation. Beard interestingly sees Baldwin's attention to this inescapable bond of relatedness not as an obstacle to black separatism, but 
rather as an obvious rationale for why the "practice of separatism ... as a political-interpersonal tactic" might be needed in the face of such shared histories of violence, which Baldwin's exilic life outside of America makes plain. ${ }^{10}$

Two notable articles published during this period deepen the use of interdisciplinary methods in Baldwin studies and speak to the creative discoveries that arise when placing Baldwin in dialogue with emergent critical approaches. In the 2016 volume of $J B R$, David McIvor illuminates the linkages alive among object relations psychoanalytic theory and Baldwin's work in “The Struggle of Integration: James Baldwin and Melanie Klein in the Context of Black Lives Matter." Providing a detailed, helpful overview of Klein's postwar contributions to object relations psychoanalysis and Baldwin's concomitant skepticism of psychoanalysis, McIvor goes on to identify thoughtful "resonances" between these authors' writings to "show how the work of Klein and Baldwin complements each other and mutually illuminates the pathologies and possibilities of our ambivalent racial present." 11 McIvor argues that "Klein's idea of integration as the habitual attainment of a sense of reality, the overcoming of omnipotence and the mature acceptance of ambivalence within self and other, still rings clearly in Baldwin," and his work "reveals the urgent politics of [Klein's concept of] the depressive position." ${ }^{2}$ Turning to the growing contemporary field of trans studies, Marquis Bey takes up trans methodologies to explore what he calls the "trans-ness" of Baldwin, illuminated in his category-destroying final novel Just Above My Head (1979). Bey frames his argument within the context that recent theorizations of "trans" are now being employed as "a way to critique master narratives of identity," whether gender, racial, or sexual identity. ${ }^{13}$ Interestingly, he argues that Baldwin's "trans-ness is not reducible to identity ... The trans that Baldwin enacts involves his interstitial (non)placement between two othered selves-one preceding and one ahead of him-and it is this pseudo-place, this non-categorized and ever-beyondness that he always inhabits." 14

Further demonstrating the growing impact that the interdisciplinary study of race has had on philosophy and political theory, in 2015 the journal Critical Philosophy of Race published a special issue on "James Baldwin and Philosophy." The product of an ongoing editorial collaboration between John E. Drabinski and Grant Farred, both leaders in the field of African-American studies, this issue focused on Baldwin's contribution to the "philosophy of race," with its stated goal to engage "Baldwin as a philosopher, as a thinker who raises fundamental questions, questions that go to the core of what it means to be in the world." 15 Articles in this issue implement a philosophical framework to analyze some of the author's most important, yet understudied works on race, including "Blacks are Anti-Semitic because they are Anti-White" (1967), The Evidence of Things Not Seen (1985), and "If Black English Isn't a Language, Then Tell Me, What Is?" (1979). Together they illuminate what Drabinksi and Farred call "Baldwin's Logos"-a philosophical aperture onto debates about the power of language, temporality, and identity. Along with Farred's essay reviewed above, Drabinski offers a deft reading of Baldwin's late writings on language, the vernacular, and black culture, employing ideas 
from Du Bois, Fanon, and Heidegger to assert the ways that Baldwin's conception of black English serves as a vehicle for self-knowledge and animates a sense of being in the world. Also in this volume, Jonathan Eburne explores Baldwin's meditation on the terror arising from the 1979-81 Atlanta child murders in a reading of The Evidence of Things Not Seen that employs a philosophical consideration of negation as a means of critically revealing the "moral vacuum that lay beneath" the "terror" of these crimes. ${ }^{16}$ Re-reading Baldwin's act of witnessing in the text, Eburne argues that: "in a performative demonstration of his negative approach to the truth of racial terror, Baldwin refuses the dialectical negation according to which terror might be rehabilitated as justice or a revolutionary imperative; he argues instead that such a dialectic merely renders the accounts all the more imbalanced." ${ }^{17}$ Bringing new life to Baldwin's post-civil rights era nonfiction writings, Drabinski and Farred's edited volume illuminates the searing philosophical questions that continued to animate Baldwin in his last years, while also making an important inroad into an ongoing effort to diversify the field of philosophy.

In her monograph, Physics of Blackness: Beyond the Middle Passage Epistemology (2015), longtime Baldwin scholar Michelle M. Wright delves into the disciplinary intersections between philosophy and literature, in particular exploring the field of phenomenology. Taking this interdisciplinary topic into uncharted territory, the book incorporates a novel "use of lay discourses on spacetime in particle or quantum physics . . to uncover how and why these distinct spacetimes operate and to trace their attendant effects on concepts of Black agency."18 The resultant analysis of blackness as defined by an "epiphenomenal spacetime," which complicates linear progressive temporalities, provides an interesting vantage point from which to re-read Baldwin's essay collection Notes of a Native Son (1955). In her chapter claiming Baldwin's multidimensional representation of blackness as resonant with quantum theory, Wright argues that "Blackness must be read outside of the wholly vertical, in which it can be interpellated only as the object of and, at best, a reactor against white racist agency," going further to claim that the last four chapters of Notes crafts a pattern of "horizontal interpellation" which is particular to a postwar sense of interracial, masculine alienation. ${ }^{19}$ Besides Wright's unique infusion of theoretical physics into her reading of Baldwin's work, she also forwards an important criticism of the author's failure to account for women's experiences in Notes, a fact clarified by an analysis of the horizontal and vertical dimensions of affiliation in the collection and furthered through Wright's thoughtful comparative reading of Ama Ata Aidoo's Our Sister Killjoy (1977).

Also of worthy note are two strong contributions to the study of James Baldwin in the field of jazz studies. Rashida K. Braggs's 2016 monograph, Jazz Diasporas: Race, Music and Migration in Post-World War II Paris, considers Paris to be a unique environment of diasporic migration and jazz performance, conceiving "jazz diasporas" as signifying the "geographically, historically situated cultural spaces that support and spur flexibility, negotiation, and shifting of racial and national identities for migrating African American jazz musicians and communities of jazzo-philes with whom they collaborate." ${ }^{20}$ Her chapter comparing James 
Baldwin and French writer Boris Vian's composition of blues literature advances our understanding of the transnational histories of collaboration and convergence that shaped Baldwin's perspectives on the blues. Focusing in on what she terms "dislocated listening," a dynamic most evident in the analysis of Baldwin's story "Sonny's Blues" (1957), Braggs argues that listening to jazz away from home, in diaspora, "creates distance that prompts disorientation, discomfort, vulnerability, and openness to new experiences." For Baldwin, this took the form of the author's efforts to face the history of violence and suffering that shaped African-American life and catalyzed the mix of "tragicomedy" and "liberation" found in the blues. ${ }^{21}$ Emily Lordi's article "James Baldwin and the Sound of Soul," which appeared in CR: The New Centennial Review's 2016 special section dedicated to Baldwin, explores Baldwin's relationship to soul music, an important black musical form that has received little attention compared to jazz and blues in Baldwin criticism. Re-reading Baldwin's writings on black music in the context of Phyl Garland's interpretation of Baldwin in her groundbreaking The Sound of Soul, Lordi offers a compelling argument for Baldwin's unique vision of soul, which "like sensuality, was best understood as process and practice." 22 The article charts this process through thoughtful readings of Baldwin's representation of soul in Just Above My Head (1979) as well as interpretations of the music of Ray Charles, who was one of Baldwin's most beloved singers, concluding with an illuminating close reading of Charles's "Georgia on my Mind," which Lordi interprets as formally evoking "Baldwin's ideas of black struggle and survivorship." ${ }^{23}$

As the scholarly record on Baldwin expands to include multiple ways of knowing and methodological applications, the field moves forward, toward new and unforeseen futures for Baldwin criticism and research. This attention to innovative multidisciplinary approaches within the field, however, is complemented by a persistent dedication to historical and archival research. An experiential and intellectually multidimensional practice of historicism has long been a strength of Baldwin criticism, and the community's scholarly fascination and respect for the intricacies of Baldwin's biography, place in history, and relationships with others continue to be animating forces for scholarship produced between 2015 and 2016 . To read Baldwin's work as a window onto paradoxical, interconnected histories is to illuminate how the past lives in the present as both embodied and remembered experience. As Ed Pavlić describes Baldwin's increasingly experiential understanding of history in Who Can Afford to Improvise: James Baldwin and Black Music, the Lyric and the Listeners (2015): for Baldwin, "Americans' most important access to history was through the present-tense texture of their lives, presence-sense; and, that experience of history's presence-tense depended upon a neglectedeven avoided-presence-sense, people's actual relationships to each other." ${ }^{24}$ For members of the Baldwinian artistic and scholarly community, history is not simply a distanced object of research, but is also inevitably a sensorial experience often sparked by rich connections with others.

Perhaps the most exciting trend related to historical and biographical approaches is the growing body of in-depth, archival research that enriches the existing 
historical record of Baldwin's life. What might be called the archival turn in Baldwin studies, this third major trend of the period registers the growing momentum to protect and make accessible Baldwin's literary archive, a long-sought goal that culminated in the spring of 2017 when the Schomburg Center for Research in Black Culture announced its acquisition of the James Baldwin papers, facilitated by Baldwin's sister and literary executor, Gloria Karefa-Smart. The renewed scholarly attention to archival practice and theory during 2015-16 brings with it a critical emphasis on the roles of embodiment, materiality, and self-reflection in the process of knowledge production within the field. To encounter Baldwin's letters, his telephone bills, or his edited page proofs brings with it a different ethic in academic study, one that bears greater responsibility for the care of and respect for Baldwin's legacy, as well as of those of his surviving family and friends whose lives are also intimately held in the archive. Thus, for many Baldwin scholars such as Magdalena Zaborowska, Douglas Field, and Ed Pavlić, the work of archival research brings with it an engagement with a larger circle of colleagues, friends, and family whose stories and memories are an essential complement to the material record of Baldwin's work.

Attention to the archival developments in Baldwin studies must account for the publication of important primary and secondary source material integral to the goal of maintaining an open public archive of ideas for Baldwin readers and scholars. One important milestone in this scholarly effort can be seen in the 2015 re-issuing of David Leeming's seminal biography James Baldwin, first published in 1994, yet out of print for a number of years. Beyond its literary merits, Leeming's biography is unique in that it draws on the author's own storehouse of personal experiences and memories of Baldwin that were cultivated over their decades-long friendship that began when they met in Istanbul in 1961. Leeming's experience working as Baldwin's personal secretary and later organizing Baldwin's papers after his death, at the behest of his brother David Baldwin, gives him a strong archival and material grounding from which to provide a historical account of Baldwin's life. Leeming's biography is essential to our critical understanding of the intersections and ambivalences surrounding Baldwin's various political, racial, and sexual identities - an archival and historical work that seems particularly invaluable when set in contrast to the relative scarcity of first-hand accounts of the lives of other black queer artists of Baldwin's day, such as Lorraine Hansberry.

Turning to innovative criticism infused with new archival insights that was published during this period, Douglas Field's 2015 All Those Strangers: The Art and Lives of James Baldwin provides a fresh perspective on Baldwin's life through a creative infusion of new critical interpretation and extensive archival research. The most impactful of the book's contributions is Field's exploration of Baldwin's radical political activities through the lens of the author's FBI file, a complex archival document numbering 1,884 pages that Field closely analyzes with wry, scholarly attention. In Field's words, this FBI file provides an important "political biography" of Baldwin, in its documentation of "Baldwin's energy and commitment to a wide range of political activity." ${ }^{25}$ In turn, by looking to the FBI's 
treatment of Baldwin, which includes transcripts of Baldwin's televised addresses, agent accounts of non-credible gossip, thoroughly incompetent readings of literature and essays as well as provocative marginalia by J. Edgar Hoover himself, Field provides a portrait of the values and assumptions the FBI and its COINTELPRO arm brought to their investigations of the civil rights and Black Nationalist movements. Blending archival research with careful historical criticism, Field also turns to understudied topics such as Baldwin's activities in leftist publications in the 1940s, his contested status as a religious writer and thinker, and his complicated relationship to exile and transnational belonging. All Those Strangers thus seeks to forward a "new kind of critical reading" that is "in step with the political, cultural and literary developments that his work inhabits but also one that recognizes the harmony of paradox and contradiction - to 'recreate, as Baldwin wrote early in his career, 'out of the disorder of life that order which is art." ${ }^{26}$ Field's contributions in All Those Strangers, then, are both archival and critical, a subtle melding of close critical analysis of "minor" texts, such as Baldwin's 1940s literary reviews, with an archive-rich biographical portrait of Baldwin's many selves.

One of the innovative uses of archival material found in recent Baldwin criticism is the exploration of primary documents as a means of opening up new theoretical and experimental approaches that expand the boundaries of traditional literary criticism. Nadia Ellis's 2015 Territories of the Soul: Queered Belonging in the Black Diaspora offers a prime example of the productive insights that can be born from the merging of archival discovery with theoretical innovation. In Territories, Ellis explores what she calls "queer diasporic belonging" that is framed by experiences of negation, disunion, and missed connection between and among black and sometimes queer authors participating in the Negritude and Caribbean Arts movements of mid-century London. Ellis describes her project as one in which

it is failed affinity that most often drives the tension I observe in my exemplifying texts between a desire to belong and a desire to flee the strictures of ground and community ... Queer theory guides my traversal of critical orientations between pessimism and celebration, orientations that are often held to be worlds apart. ${ }^{27}$

Contributing to a greater understanding of Baldwin's relationship to Caribbean thinkers and writers, Ellis offers a comparative analysis of James Baldwin and George Lamming who both attended, and wrote about, the 1956 Paris Congress of Negro Artists and Writers. Interestingly, the happenstance and fragmentary process of archival research, which Ellis experienced in the archive of the Caribbean Arts movement, as well as the unusual crossings of source material found in her chapter on Baldwin and Lamming_including essays by Baldwin and Lamming on the 1956 meeting, letters from Kamau Brathwaite, and Horace Ovés film Baldwin's Nigger (2004) - mirror the "textual missed connections" that shaped Baldwin's encounter with Lamming in the 1950s and 1960s, particularly in his essay "Princes and Powers." While both authors shared metaphoric fraternal affinities, similarly conceiving of themselves as "unclaimed sons" of "the West" in their 
writings about black diaspora, they were never friends. ${ }^{28}$ Here, Ellis focuses on the divisions that persisted between them, even in light of their shared language, writing of Baldwin's vision of diaspora as not just "difference; it is diaspora as disavowal. This is diaspora made through the coming together of people mutually claiming to have no relation to each other. It is therefore the claim of separateness that constitutes the connection." 29

We can learn something from the ways that Baldwin criticism touches on particular historical moments in Baldwin's life with added significance, particularly during the two years that mark the less-than-hopeful tail-end of Obama's presidency and a resurgent moment of national anti-racist protest. These historical touchstones include the 1956 Paris Congress, Baldwin's 1965 debate with William F. Buckley at Cambridge University, and his 1969 speech at London's West Indian Student Center that is documented in Ovés Baldwin's Nigger. Providing evidence for the importance of an open-access archive of primary materials, scholarly interest in Ovés film and Baldwin's debate with Buckley may be gaining new attention due to the fact that both the film and the televised recording of the Baldwin vs. Buckley debate are available on YouTube, both first uploaded in the fall of $2010 .^{30}$ Ellis's interest in these events is shared by John Drabinski who looks to Baldwin's attendance at the Congress in his exploration of Baldwin's writings on African movements for decolonization and in particular the figures of Haile Selassie, Aimé Césaire, and Kwame Nkrumah. Drabinski's article "Baldwin's Three Africans" published in the 2016 special section of CR: The New Centennial Review, which he co-edited with Farred, is accompanied by Farred's article on "Baldwin in Britain" that features an analysis of Ovés film alongside Baldwin's debate with William F. Buckley. Daniel Robert McClure further analyzes the Baldwin-Buckley debate in his article that appeared in the 2016 volume of $J B R$. Finally, Danielle C. Heard focuses on Baldwin's wry humor in Ovés film in her chapter "Baldwin's Humor" in the 2015 Cambridge Companion to James Baldwin. Beyond registering a continued scholarly interest in the transnational dimensions of Baldwin's life and work, these events now documented in an increasingly multimedia archive turn our attention toward Baldwin's exploration of Black Nationalism's radical promise on a global stage.

The 2016 publication of Ed Pavlićs Who Can Afford to Improvise exemplifies the turn in Baldwin criticism toward melding artistic and theoretical experimentation with archival practice. Pavlićs syncopated portrait of Baldwin's relationship to black music and lyric form intimately attends to "the importance of listening, of hearing, and of music" in Baldwin's work and life. ${ }^{31}$ This critical emphasis on listening frames both the structure and content of the book, challenging us to accompany the author as he takes up an aural, embodied practice of literary and historical reception that dwells in the "notion of the lyric as a generally disruptive propensity of language, a metaphorically or literally musical interruption of the report-function usually assigned to what is called prose." ${ }^{2}$ This study is therefore not about Baldwin writing about music, but about Baldwin's writing as music-an animating subject that shapes the errant circulations of, and riffs on, the textual, aural, and archival source material that Pavlić brings to the monograph. Who Can 
Afford incorporates biographical narratives of Baldwin's literary production and radically artistic life alongside analyses of encounters between Baldwin, the music that inspired him, and the music that his work inspired. A far-reaching, early chapter in the monograph traces the "long, shifting song . . . of what Baldwin attempted to make words, his words, do" throughout his musically informed career, while a middle chapter offers a lyrical "short trip through Billie Holiday's career as a singer" that originates from Baldwin's claim that she was a true poet and concludes with Pavlić touching upon the theme of improvisation so important to Baldwin's art: "[Holiday] taught [Baldwin] that, at bottom, improvising meant living the lyric and lining the life." ${ }^{33}$ The book concludes with a section that speaks to the contemporary resonances of Baldwin's lyric experiments, exploring a range of subjects such as one chapter dedicated to Amy Winehouse's dangerous use of lyric in the context of the transatlantic racial politics of soul. ${ }^{34}$

While Who Can Afford is not explicitly about the archive, nor does it incorporate a great deal of archival material from Baldwin's estate, the author's archival encounters considerably contribute to the steady pulse of critical experimentation at work in the text. During the time of the monograph's composition, Pavlić had the exciting, and very unusual, privilege of studying and transcribing a collection of Baldwin's letters to his brother David, who the critic describes as perhaps "the closest person to him in the world." ${ }^{35}$ In describing this scholarly experience, which occurred thanks to the invitation of Baldwin's sister Gloria Karefa-Smart, Pavlić speaks of walking into an intimate encounter with Baldwin's letters that was akin to a practice of listening and sensing the haptic quality of the author's voice. He writes: "the letters brought my ear very, very close to aspects of the published work and public speeches that wouldn't have sounded like they did to me had I not listened so closely to what Baldwin had told his brother about it all in his letters." ${ }^{36}$ Like the ear-training that musicians employ to better recognize if a note is in tune, Pavlićs acts of listening in the Baldwin archive helped him hear new voices in Baldwin's published work. Thus, his archival process gives him new insight into those small moments of listening in Baldwin's life that speak volumes to his compositional process and poetic relation to music more broadly, such as the impact that listening to Aretha Franklin's 1967 album Aretha Arrives had on Baldwin's approach to telling the story of Malcolm X in his never produced screenplay.

Currents, directions, trajectories, trends; there are a wealth of metaphors, and conceptual approaches, that one could take in making meaning of the exciting developments in James Baldwin criticism between 2015 and 2016. In turn, there are more articles, chapters, books, and conference presentations circulating during this period than a 7,000-word review could possibly address, making it provisional by design. Yet I have sought here to offer a humble collection of bibliographic observations that center on the period's expansion of scholarly homes for Baldwin criticism as well as on an increasing emphasis on archival research in strengthening our historical understanding of Baldwin, his creative process, and his political 
impact. As many critics have argued, Baldwin's literature dwells in the gaps, fissures, and borderlands of the twentieth century. The increasingly capacious landscape of scholarly production in 2015-16 thus continues to bear respect to, and regard for, the errant constellation of places, people, and ideas that are so very much alive in Baldwin's work.

\section{Notes}

1 Frederick C. Harris, "James Baldwin, 1963, and the House that Race Built," Transition, 115 (2014), p. 66.

2 Michelle Elam, "Review of New York City's 'The Year of Baldwin," James Baldwin Review, 1 (2015), p. 204.

3 Ernest L. Gibson III, “Trends in James Baldwin Criticism 2013-15," James Baldwin Review, 4 (2018), p. 130.

4 Mason Stokes, "A Brutal, Indecent Spectacle': Heterosexuality, Futurity, and Go Tell It On the Mountain," MFS Modern Fiction Studies, 62:2 (2016), p. 293.

5 Ibid., p. 302.

6 Laila Amine, "The Paris Paradox: Colorblindness and Colonialism in African American Expatriate Fiction," American Literature, 87:4 (2015), p. 740.

7 Christopher Stuart, "Finding the Jimmy in James: How James Baldwin Discovered Giovanni's Room in Lambert Strether's Paris," MELUS, 40:2 (2015), p. 63.

8 Spencer Morrison, "James Baldwin on Vacation in Another Country," ELH, 83 (2016), p. 905 .

9 Grant Farred, "Love Is Asymmetrical: James Baldwin's The Fire Next Time," Critical Philosophy of Race, 3:2 (2015), p. 300.

10 Lisa A. Beard, "'Flesh of their Flesh, Bone of their Bone': James Baldwin's Racial Politics of Boundness," Contemporary Political Theory, 15:4 (2016), p. 386.

11 David W. McIvor, "The Struggle of Integration: James Baldwin and Melanie Klein in the Context of Black Lives Matter," James Baldwin Review, 2 (2016), p. 77.

12 Ibid., p. 88.

13 Marquis Bey, "The Song Required of Captivity: Just Above My Head and the Trans-ness of James Baldwin," Palimpsest: A Journal on Women, Gender and the Black International, $5: 1$ (2016), p. 44.

14 Ibid., p. 51.

15 John E. Drabinski and Grant Farred, "Introduction: On Baldwin and Philosophy," Critical Philosophy of Race, 3:2 (2015), p. 176.

16 Jonathan Eburne, "The Terror of Being Destroyed," Critical Philosophy of Race, 3:2 (2015), p. 268.

17 Ibid., p. 276.

18 Michelle M. Wright, Physics of Blackness: Beyond the Middle Passage Epistemology (Minneapolis, MN, University of Minnesota Press, 2015), p. 4.

19 Ibid., pp. 113-14.

20 Rashida K. Braggs, Jazz Diasporas: Race, Music and Migration in Post-World War II Paris (Berkeley, CA, University of California Press, 2016), p. 5.

21 Ibid., p. 133.

22 Emily J. Lordi, "James Baldwin and the Sound of Soul," CR: The New Centennial Review, $16: 2$ (2016), p. 32. 
23 Ibid., p. 42.

24 Ed Pavlić, Who Can Afford to Improvise: James Baldwin and Black Music, The Lyric and the Listeners (New York, Fordham University Press, 2017), p. 102.

25 Douglas Field, All Those Strangers (Oxford, Oxford University Press, 2015), p. 47.

26 Ibid., p. 7.

27 Nadia Ellis, Territories of the Soul: Queer Belonging in the Black Diaspora (Durham, NC, Duke University Press, 2015), p. 6.

28 Ibid., pp. 63, 73.

29 Ibid., p. 80.

30 Ovés film has reached over 100,000 viewers and the debate surprisingly registers over 1.4 million viewers.

31 Pavlić, Who Can Afford to Improvise, p. 6.

32 Ibid., p. 7.

33 Ibid., pp. 43, 148.

34 Ibid., p. 258.

35 Ibid., p. 17.

36 Ibid.

\section{Works Cited}

Amine, Laila, "The Paris Paradox: Colorblindness and Colonialism in African American Expatriate Fiction," American Literature: A Journal of Literary History, Criticism, and Bibliography, 87:4 (2015), pp. 739-68.

Beard, Lisa A., "'Flesh of their Flesh, Bone of their Bone': James Baldwin's Racial Politics of Boundness," Contemporary Political Theory, 15:4 (2016), pp. 378-98.

Bey, Marquis, "The Song Required of Captivity: Just Above My Head and the Trans-Ness of James Baldwin," Palimpsest: A Journal of Women, Gender, and the Black International, 5:1 (2016), pp. 42-58.

Braggs, Rashida K., Jazz Diasporas: Race, Music and Migration in Post-World War II Paris (Berkeley, CA, University of California Press, 2016).

Cleary, Emma, "Here Be Dragons': The Tyranny of the Cityscape in James Baldwin's Intimate Cartographies," James Baldwin Review, 1 (2015), pp. 91-111.

Connolly, Andrew, "Shame, Rage, and Endless Battle: Systemic Pressure and Individual Violence in James Baldwin's Go Tell It on the Mountain," The CEA Critic, 77:1 (2015), pp. 120-42.

Dean, Terrance, "Fire This Time: James Baldwin, Futurity, and a Call and Response," Black Theology, 14:1 (2016), pp. 69-83.

Drabinski, John E., "Baldwin's Three Africans," CR: The New Centennial Review, 16:2 (2016), pp. 81-96.

"Vernaculars of Home," Critical Philosophy of Race, 3:2 (2015), pp. 203-26. and Grant Farred, "Introduction: On Baldwin and Philosophy," Critical Philosophy of Race, 3:2 (2015), pp. 175-9.

Eburne, Jonathan, "The Terror of Being Destroyed," Critical Philosophy of Race, 3:2 (2015), pp. 259-83.

Elam, Michelle, "Review of New York City's 'The Year of Baldwin," James Baldwin Review, 1 (2015), pp. 202-6.

Ellis, Nadia, Territories of the Soul: Queered Belonging in the Black Diaspora (Durham, NC, Duke University Press, 2015).

Farred, Grant, "Baldwin in Britain," CR: The New Centennial Review, 16:2 (2016), pp. 1-15. 
Farred, Grant, "Love Is Asymmetrical: James Baldwin's The Fire Next Time," Critical Philosophy of Race, 3:2 (2015), pp. 284-304.

Field, Douglas, All Those Strangers: The Art and Lives of James Baldwin (Oxford, Oxford University Press, 2015).

Gibson, Ernest L., “Trends in James Baldwin Criticism 2013-15," James Baldwin Review, 4 (2018), pp. 128-43.

Harris, Fredrick, “James Baldwin, 1963, and the House That Race Built," Transition, 115 (2014), pp. 52-67.

Heard, Danielle C., "Baldwin's Humor," in Michele Elam (ed.), The Cambridge Companion to James Baldwin (Cambridge, Cambridge University Press, 2015), pp. 100-17.

Leeming, David, James Baldwin: A Biography (New York, Arcade, 2015).

Lordi, Emily J., "James Baldwin and the Sound of Soul," CR: The New Centennial Review, 16:2 (2016), pp. 31-45.

McIvor, David W., "The Struggle of Integration: James Baldwin and Melanie Klein in the Context of Black Lives Matter," James Baldwin Review, 2 (2016), pp. 75-96.

Melton, McKinley E., "I've Got a Testimony: James Baldwin and the Broken Silences of Black Queer Men," James Baldwin Review, 2 (2016), pp. 6-27.

Miller, Quentin D., "Trends in James Baldwin Criticism 2010-13," James Baldwin Review, 3 (2017), pp. 186-202.

Morrison, Spencer, “James Baldwin on Vacation in Another Country," ELH, 83:3 (2016), pp. 899-925.

Pavlić, Ed, Who Can Afford to Improvise? James Baldwin and Black Music, the Lyric and the Listeners (New York, Fordham University Press, 2015).

Roszak, Suzanne, “Sex, Diaspora, and the New 'Italian Novel': James Baldwin's Giovanni's Room and Bernard Malamud's Pictures of Fidelman," Arizona Quarterly: A Journal of American Literature, Culture, and Theory, 71:4 (2015), pp. 81-106.

Schwarz, Bill, "After Decolonization, After Civil Rights: Chinua Achebe and James Baldwin," James Baldwin Review, 1 (2015), pp. 41-66.

Stokes, Mason, "'A Brutal, Indecent Spectacle': Heterosexuality, Futurity, and Go Tell It on the Mountain," MFS: Modern Fiction Studies, 62:2 (2016), pp. 292-306.

Stuart, Christopher, "Finding the Jimmy in James: How James Baldwin Discovered Giovanni's Room in Lambert Strether's Paris," MELUS: The Journal of the Society for the Study of the Multi-Ethnic Literature of the United States, 40:2 (2015), pp. 53-73.

Vogel, Joseph, “'To Crush the Serpent': James Baldwin, the Religious Right, and the Moral Minority," James Baldwin Review, 2 (2016), pp. 28-48.

Wright, Michelle M., Physics of Blackness: Beyond the Middle Passage Epistemology (Minneapolis, MN, University of Minnesota Press, 2015).

\section{Contributor's Biography}

Jenny M. James is Associate Professor of English at Pacific Lutheran University in Tacoma, Washington, where she teaches courses on contemporary American literature and critical race, gender, and sexuality studies. Her work has been published in GLQ: A Journal of Lesbian and Gay Studies, MELUS: Multi-ethnic Literature of the U.S., James Baldwin Review, Studies in American Fiction, and James Baldwin in Context forthcoming from Cambridge University Press. She is currently working on a book-length study of debt, artistic collaboration, and interracial, queer kinship in mid-century American literature. 